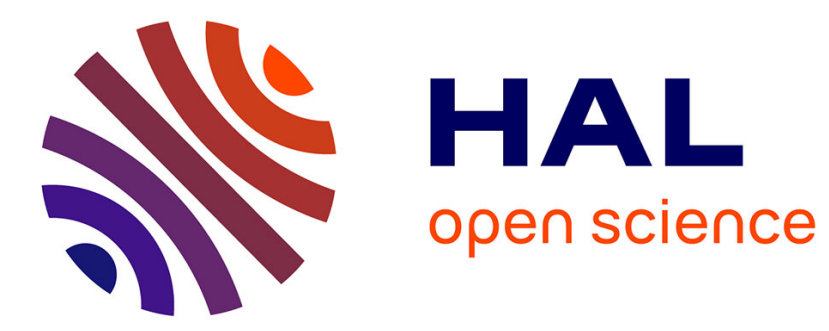

\title{
Iron isotopes in the seawater of the equatorial Pacific Ocean: New constraints for the oceanic iron cycle
}

\author{
A. Radic, F. Lacan, J. W. Murray
}

\section{To cite this version:}

A. Radic, F. Lacan, J. W. Murray. Iron isotopes in the seawater of the equatorial Pacific Ocean: New constraints for the oceanic iron cycle. Earth and Planetary Science Letters, 2011, 306, pp.1-10. 10.1016/j.epsl.2011.03.015 . hal-00646846

\section{HAL Id: hal-00646846 https://hal.science/hal-00646846}

Submitted on 19 Jan 2012

HAL is a multi-disciplinary open access archive for the deposit and dissemination of scientific research documents, whether they are published or not. The documents may come from teaching and research institutions in France or abroad, or from public or private research centers.
L'archive ouverte pluridisciplinaire HAL, est destinée au dépôt et à la diffusion de documents scientifiques de niveau recherche, publiés ou non, émanant des établissements d'enseignement et de recherche français ou étrangers, des laboratoires publics ou privés. 


\title{
Iron isotopes in the seawater of the equatorial Pacific Ocean : new constraints for the oceanic iron cycle
}

\author{
Amandine Radic ${ }^{a}$, François Lacan ${ }^{a, *}$, James W. Murray ${ }^{b}$
}

\author{
a Laboratoire d'Etudes en Géophysique et Océanographie Spatiale, Université Paul Sabatier / CNRS, \\ Observatoire Midi Pyrénées, F-31400, Toulouse, France, \\ ${ }^{b}$ School of Oceanography, University of Washington, Seattle, Washington, USA \\ *Corresponding author. Tel. : +33561333043; Fax. : +33561253205; Email address : \\ Francois.Lacan@legos.obs-mip.fr (F. Lacan).
}

\section{Abstract}

This study presents the isotopic compositions and concentrations of dissolved and particulate iron from two seawater profiles of the western and central equatorial Pacific Ocean, sampled during the EUCFe cruise. Most of the $\delta^{56} \mathrm{Fe}$ values are positive (relative to IRMM-14), from +0.01 to $+0.58 \%$ o in the dissolved fraction and from -0.02 to $+0.46 \%$ in the particulate fraction. The mean measurement uncertainty is $\pm 0.08 \%$ (2SD) and allows the observation of significant variations. Largest isotope variations occur in the vertical and not in the horizontal direction, implying that each isotope signature is preserved over long distances within a water mass.

The thermocline waters of the Papua New Guinea (PNG) area, mostly influenced by sedimentary inputs, display a mean $\delta^{56} \mathrm{DFe}$ value of $+0.37 \%$ ( $\left.\pm 0.15 \%, 2 \mathrm{SD}\right)$. This isotopic signature suggests that the process releasing dissolved iron to the seawater in this area is non reductive dissolution of sediments (discharged by local rivers and likely re-suspended by strong boundary currents), rather than Dissimilatory Iron Reduction (DIR) within the sediment (characterized by negative $\delta^{56} \mathrm{DFe}$ ). These positive $\delta^{56} \mathrm{DFe}$ values seems to be the result of an isotopic fractionation of $\Delta^{56} \mathrm{Fe}_{\mathrm{DFe}-\mathrm{PFe}}=+0.20 \%$ on average $( \pm 0.11 \%, 2 \mathrm{SD})$ produced by the non reductive dissolution. At $0^{\circ} \mathrm{N}$, $180^{\circ} \mathrm{E}$, the Fe isotope signature of the Equatorial Undercurrent (EUC) waters is identical to that of the PNG station within the range of the uncertainty. This suggests that the iron feeding the EUC, and ultimately the eastern Pacific high nutrient low chlorophyll area, is of PNG origin, likely released by a non reductive dissolution of terrigenous sediments.

Significant Fe removals are observed within the thermocline and the intermediate waters between the PNG and the open ocean stations. The corresponding isotopic fractionations appear to

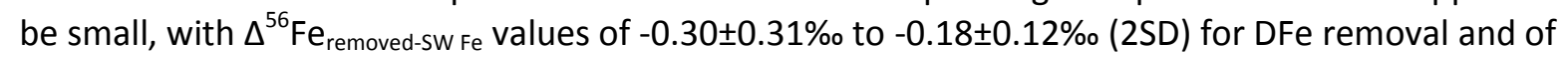
$-0.10 \pm 0.04 \%$ o to $-0.05 \pm 0.31 \%$ o (2SD) for PFe removal. In the chlorophyll maximum of the open ocean station, the isotopic fractionation associated with biological uptake is estimated at $\Delta^{56} \mathrm{Fe}_{\text {phyto-DFe }}=$ $-0.25 \pm 0.10 \%$ o to $-0.13 \pm 0.11 \%$ o (2SD). Although these fractionations are based on limited dataset and need to be further constrained, they appear to be small and to limit the transformations of the iron source signatures within the ocean.

Keywords: (6) iron isotopes, Equatorial Undercurrent, Papua New Guinea, equatorial Pacific, dissolved and particulate iron, biogeochemical cycle 


\section{Introduction}

In wide regions of the ocean, phytoplankton growth does not use all of the available macronutrients. Such regions are called High Nutrient Low Chlorophyll (HNLC) areas (Southern Ocean, subartic and equatorial Pacific Oceans). Martin (1990) hypothesized that fertilization of the Southern Ocean with iron could have increased primary production and contributed to the $\mathrm{CO}_{2}$ drawdown observed in the last glacial maximum. This hypothesis motivated numerous studies focused on iron during the last 2 decades. Although these studies revealed that Martin's "iron hypothesis" could only explain a fraction of the last glacial maximum $\mathrm{CO}_{2}$ drawdown (Kohfeld et al., $2005)$, they confirmed the key role played by iron in the biological and chemical oceanic cycles (e.g., Boyd et al., 2007).

In seawater, iron occurs in two oxidation states, $\mathrm{Fe}(\mathrm{II})$ and $\mathrm{Fe}(\mathrm{III})$, and in a wide range of chemical species. Although Fe(III) is the least soluble form, it is the thermodynamically favored form in oxic seawaters and the most abundant. Organic ligands complex to more than $90 \%$ of the dissolved iron (DFe) and control the solubility of the dissolved pool (Rue and Bruland, 1995 ; Kuma et al., 1996 ; Johnson et al., 1997). The particulate iron pool (PFe) encompasses biogenic forms (phyto/zooplankton and non-living organic matter) and inorganic forms. All these forms interact through numerous processes like biological uptake / degradation, adsorption / desorption, and precipitation / dissolution (e.g., de Baar et de Jong, 2001 ; Ussher et al., 2004). Uncertainties remain about these processes, such as the effect of organic complexation on the kinetics of the phase transitions, biological uptake, scavenging and on Fe bioavailability (Ussher et al., 2004). The Fe distribution in the ocean results from the balance between its sources and sinks. The only sink is the removal by settling particles whereas there are numerous potential iron sources. In the open ocean the main DFe source was traditionally considered to be atmospheric deposition (Jickells et al., 2005). During the last decade, numerous studies suggested that sedimentary inputs also have a significant impact on the global oceanic iron budget. These include shelf iron flux measurements in benthic chambers, water column Fe concentrations measurements and modeling (e.g., Coale et al., 1996; Elrod et al., 2004; Lam et al., 2006; 2008; Moore and Braucher, 2008; Slemons et al.,2009; Tagliabue et al., 2009; Severmann et al., 2010). Recently, hydrothermal contribution to surface DFe has been suggested to be significant, especially in the Southern Ocean (Tagliabue et al., 2010). However the relative importance of these different iron sources still remains to be quantified, in particular in HNLC areas.

Recent studies have suggested using the DFe isotope composition in the water column as a tracer of iron sources (Lacan et al., 2008; John and Adkins, 2010). The iron isotope composition is expressed by $\delta^{56} \mathrm{Fe}$ defined as : $\delta^{56} \mathrm{Fe}=\left[\frac{\left({ }^{56} \mathrm{Fe} /{ }^{54} \mathrm{Fe}\right)_{\text {sample }}}{\left({ }^{56} \mathrm{Fe} /{ }^{54} \mathrm{Fe}\right)_{\text {IRMM }-14}}-1\right] \times 10^{3}$. In the following, the values of $\delta^{56} \mathrm{Fe}$ are reported relative to the IRMM (the $\delta^{56} \mathrm{Fe}$ of igneous rocks relative to IRMM is of $+0.09 \pm 0.1 \%$ o, $2 \mathrm{SD}$; Beard et al., 2003a). The potential of this emerging tracer is notably related to the two distinct isotopic imprints of its main sources to the open ocean. $\delta^{56} \mathrm{Fe}$ values ranging from $-3.31 \%$ $\pm 0.07 \%$ o to $-1.73 \pm 0.04 \%$ o (2 SD) in coastal sediment pore waters just below the seawater interface were interpreted as reflecting bacterial iron reduction (Severmann et al., 2006 ; Homoky et al., 2009). In addition, benthic chamber measurements from the Oregon-Californian continental shelf display an average $\delta^{56} \mathrm{Fe}$ value of $-2.6 \pm 1.1 \%$ 2SD (Severmann et al., 2010). These studies imply that the diagenetic sedimentary source in reducing environments is likely characterized by a very negative $\delta^{56} \mathrm{Fe}$ signature. In contrast, aerosol $\delta^{56} \mathrm{Fe}$ values measured so far, ranging from $-0.03 \%$ o to $0.24 \pm 0.08 \%$ o (2SD; Beard et al., 2003b; Waeles et al., 2007) which is close to the crustal value : $0.07 \pm 0.02 \%$ o (2SD; Poitrasson, 2006). Some studies have characterized $\delta^{56} \mathrm{Fe}$ of other iron sources which may locally contribute to a significant flux. A few hydrothermal fluids have been measured and they display $\delta^{56} \mathrm{Fe}$ values between -0.65 and- $0.12 \pm 0.06 \%$ (2SD) in the initial fluids (Sharma et al., 
2001; Beard et al., 2003b; Rouxel et al., 2008). Concerning river inputs, a range of $-0.60 \pm 0.14 \%$ o to $+0.36 \pm 0.06 \%$ was measured in the DFe content of various fresh river waters, whereas a range of $0.90 \pm 0.04 \%$ o to $0.31 \pm 0.09 \%$ (2SD) was measured in the PFe (Bergquist and Boyle, 2006 ; Ingri et al., 2006 ; de Jong et al., 2007 ; Escoube et al., 2009). In estuarine environments, a decreasing of the $\delta^{56} \mathrm{Fe}$ (down to $-1.2 \%$ ) in the DFe pool was measured during the flocculation in the Scheldt estuary (de Jong et al., 2007), whereas no significant change was observed in the North River estuary (USA), with an average value of $+0.43 \%$ in the DFe pool (Escoube et al., 2009).

In addition to the diversity of these source signatures, the processes involved in the transformations between the different iron species could potentially fractionate iron isotopes and modify the $\delta^{56} \mathrm{Fe}$ value of the DFe pool in seawater. Their influence on $\delta^{56} \mathrm{Fe}$ still remains unclear. Although none of these processes has been directly investigated under oceanic conditions, redox conversions seem to generate the largest isotopic fractionations, leading to a $\mathrm{Fe}(\mathrm{II})$ pool enriched in light isotopes and a Fe(III) pool enriched in heavy isotopes (e.g., Johnson et al., 2008). Among the numerous studies which have estimated isotopic fractionations (corresponding to in vitro experiments mostly), some of them are reported below. Oxidation of $\mathrm{Fe}(\mathrm{III})_{\mathrm{aq}}$ to $\mathrm{Fe}(\mathrm{III})_{\mathrm{aq}}$ followed by precipitation of $\mathrm{Fe}(\mathrm{III})_{\mathrm{aq}}$ as $\mathrm{Fe}$ oxides or hematite is suggested to lead to a fractionation such that $\Delta \Delta^{56} \mathrm{Fe}$ Fe(III)solid - Fe(II)aq $\approx+0.9$ to $+3.0 \%$, the dissolved Fe(II) $)_{\text {aq }}$ remaining after these processes would then be lighter than the initial DFe (Bullen et al., 2001; Beard and Johnson, 2004). Reductive dissolution, in the presence of light and oxalate at $\mathrm{pH}=3-5$, has been shown to fractionate iron isotopes : $\Delta^{56} \mathrm{Fe}$ $\mathrm{Fe}($ III)aq-Goethite $=-1.7$ to $0 \%$ (dissolved Fe is lighter than the solid source ; Wiederhold et al., 2006) whereas proton promoted dissolution did not show any significant isotopic fractionation (Wiederhold et al., 2006; Waeles et al., 2007). Sorption mechanisms seems to fractionate Fe isotopes such that adsorbed $\mathrm{Fe}$ is heavier than the initial Fe(II) $)_{\mathrm{aq}}$ displaying a $\Delta^{56} \mathrm{Fe}_{\mathrm{Fe}}$ (II)adsorb-Fe(II)aq of +0.3 to $+0.9 \%$ for hematite and goethite respectively (Crosby et al., 2007; Johnson et al., 2008).

Complexation of iron with siderophores has been shown to fractionate iron isotopes at acidic $\mathrm{pH}$, yielding $\Delta \Delta^{56} \mathrm{Fe}_{\mathrm{Fe}(I I I) \text { siderophore-Fe(III)inorg }}=+0.60 \pm 0.15 \%$ (Dideriksen et al., 2008). Biological uptake performed by higher plants from soil iron (especially vegetables) may induce a small isotopic fractionation, incorporated iron being $0.2 \%$ heavier than the iron from soils $\left(\Delta^{56} \mathrm{Fe}_{\text {plants-soil }} \approx+0.2 \%\right.$; Guelke and Von Blanckenburg, 2007). While these isotopic fractionations may complicate the use of the iron isotopes as a source tracer, they may help understand the iron speciation in seawater.

While numerous studies report iron isotopic data in the marine environment, such as plankton tows, pore waters, aerosols, seafloor or estuaries (e.g., de Jong et al., 2007 ; Bergquist and Boyle, 2006 ; Severmann et al., 2006 ; Rouxel and Auro 2010), very few studies have provided $\delta^{56} \mathrm{Fe}$ of the seawater. Coastal seawater samples with relatively high DFe concentrations display $\delta^{56} \mathrm{DFe}$ values from $-0.3 \%$ o to $+0.2 \pm 0.14 \%$ (2SD) in the North Sea (de Jong et al. ; 2007) and from $-1.82 \pm 0.03 \%$ o to $0.00 \pm 0.09 \%$ (2SD) in the San Pedro Basin off the Californian margin (John and Adkins, 2010). Open ocean seawaters, with DFe concentration exclusively lower than $0.9 \mathrm{nM}$, have shown $\delta^{56}$ DFe ranges from +0.3 to $+0.7 \pm 0.07 \%$ (2SD) in the western Subtropical North Atlantic, (Lacan et al., 2010 ; John and Adkins, 2010), from -0.13 to $+0.21 \pm 0.08 \%$ (2SD) in the south-eastern Atlantic (Cape Basin ; Lacan et al., 2008) and from -0.49 to $-0.19 \pm 0.08 \%$ (2SD) in the Atlantic sector of the Antarctic zone (Lacan et al., 2010 ; incomplete data). Only one study reports $\delta^{56} \mathrm{Fe}$ data in the particulate fraction of the seawater and displays $\delta^{56} \mathrm{PFe}$ from -0.3 to $+0.4 \pm 0.14 \%$ (2SD) in the North Sea (de Jong et al. ; 2007). Thus iron isotope data in the ocean are nearly inexistent (especially in the open ocean). This study presents the first substantial dataset of Fe isotope compositions in the ocean, with 2 profiles of concentration and $\delta^{56} \mathrm{Fe}$ in the dissolved and particulate fractions of seawater in the upper $900 \mathrm{~m}$ of the water column in the western and central equatorial Pacific.

The western equatorial Pacific is a crossroads of water masses, those involved in the complex zonal circulation of the equatorial Pacific and those of the western boundary currents (Fine et al., 1994). The Equatorial Undercurrent (EUC, see Figure 1) carries thermocline waters along the equator 
(Lukas and Firing, 1984) from the western boundary to the eastern equatorial Pacific HNCL area (Behrenfeld et al., 1996). Numerous studies have suggested that the EUC, which is enriched in Fe from the western part of the basin and mainly from the Papua New Guinea (PNG) area, is the main source of iron to the open equatorial Pacific Ocean (e.g., Coale et al., 1996; Mackey et al., 2002; Slemons et al., 2009). Using samples from the same cruise as this study, Slemons et al (2010) showed that there was a maximum of total dissolvable Fe associated with the EUC (consistently 50-100m deeper than the maximum eastward velocity), and that this maximum was mainly composed of particulate Fe. The total Fe concentrations increased toward the west, also consistent with a western source. These studies therefore suggest that the EUC dynamic and its iron sources could control primary production in the eastern equatorial Pacific. However, there remains little understanding of the processes involved in the sources of iron to seawater in the western Pacific.

This study intends to answer to the following questions: Do the iron isotopes confirm that the Fe exported into the EUC is from the PNG area? Can they help to identify the Fe sources to the PNG area and the involved release processes? What does this new tracer teach us about the exchange processes between the different iron forms in the water column? Do these processes fractionate iron isotopes?

\section{2 sample location and water mass identification}

The samples presented in this study were collected at two stations in the equatorial Pacific Ocean during the EUCFe cruise (R/V Kilo Moana cruise 0625 ; http://www.ocean.washington.edu/cruises/KiloMoana2006) in August-September 2006. The samples presented in this study were collected over a depth range of $0-900 \mathrm{~m}$, at $0.0^{\circ} \mathrm{N} 180.0^{\circ} \mathrm{E}$ in the open ocean (station 14), and at $3.4^{\circ} \mathrm{S} 143.9^{\circ} \mathrm{E}$ near the PNG coast (station 28), as shown in Figure 1. Station 14 is an open ocean station while Station 28 is a coastal station. The regional circulation, simplified in Figure 1, indicates a continuity of the intermediate and thermocline waters between both stations, from the PNG area towards the central equatorial Pacific (Tsuchiya et al., 1989 ; Tsuchiya, 1991 ; Tsuchiya and Talley, 1996 ; Butt and Lindstrom, 1994 ; Fiedler and Talley, 2006 ; Maes et al., 2007). Figure $2 \mathrm{~A}$ shows the potential temperature $(\theta)$, salinity, and potential density $\left(\sigma_{\theta}\right)$ of the water column down to $1000 \mathrm{~m}$ at both stations (also reported at Table 1 ). These hydrographic parameters allow us to identify the water masses sampled in this study, and to point out the correspondences between the two stations. Two types of thermocline water masses were found in our profiles : the South Pacific Equatorial Water (SPEW), which is characterized by a high salinity maximum at temperatures above $20^{\circ} \mathrm{C}$ (e.g., Tomczak and Godfrey, 2003), was sampled at $191 \mathrm{~m}$ St. 28 and at $140 \mathrm{~m}$ St. 14 , and the $13^{\circ} \mathrm{C}$ water (13CW ; Tsuchiya, 1981), underneath the SPEW, was sampled at $321 \mathrm{~m} \mathrm{St.} 28$ and at $198 \mathrm{~m}$ St. 14. The Antarctic Intermediate Water (AAIW), characterized by a salinity minimum, was sampled at St. 28 at $799 \mathrm{~m}$ and at St. 14 at $849 \mathrm{~m}$. In the following, as a first order approximation, we will assume the AAIW, $13 \mathrm{CW}$ and SPEW sampled at station 14 come from the PNG area.

\section{Sampling and Methods}

The samples were collected with $10 \mathrm{~L}$ acid-cleaned Go-Flo bottles attached on a trace-metal rosette (lent by Canadian GEOTRACES, University of Victoria, Canada and assembled at the University of Washington, USA ; Slemons et al., 2010). The filtration was performed within a home made plastic room pressurized with filtered air, within 4 hours of collection, with $0.4 \mu \mathrm{m}$ pore size, $90 \mathrm{~mm}$ diameter Nuclepore membranes, fitted in Savillex PTFE filter holders, connected with PTFE tubing to 
the Go-Flo bottles pressurized with filtered air. All acids mentioned in the following were doubledistilled, and their Fe concentration measured.

The filtered seawater was acidified to $\mathrm{pH} 1.80$ two years after collection, and 3 to 9 months before the beginning of the analytical chemical treatments. The dissolved fraction were processed according to the procedure briefly described in Lacan et al. (2008) and detailed in Lacan et al. (2010). Briefly this procedure consists in a preconcentration with a NTA Superflow resin and purification with an AG1X4 anionic resin (200-400 mesh). For the entire DFe treatments, the average recovery was $91 \pm 25 \%(2 \mathrm{SD}, \mathrm{n}=55)$, the blank was $2.9 \pm 1.6 \mathrm{ng}(2 \mathrm{SD}, \mathrm{n}=8)$.

For the particulate fraction, the filters were leached during 2 steps of 90 minutes at $130^{\circ} \mathrm{C}$ in i) an aqua regia solution composed of $15 \mathrm{ml}$ of $6 \mathrm{M} \mathrm{HCl}$ and $2.5 \mathrm{ml}$ of $14 \mathrm{M} \mathrm{HNO}_{3}$ ) and ii) the same solution with an addition of $0.5 \mathrm{ml} \mathrm{HF}$ of $23 \mathrm{M}$, as describe by Lacan et al. (in preparation). Then the solution was purified using the same procedure used for the DFe samples (Lacan et al. 2010). The total analytic blank for the PFe contributed less than $10 \%$ of the natural PFe content.

The iron isotope composition was measured with a Neptune Multi-Collector Inductively Coupled Plasma Mass Spectrometer (MC-ICPMS) at the Observatoire Midi Pyrénées (Toulouse, France). $\mathrm{A}^{57} \mathrm{Fe}-{ }^{58} \mathrm{Fe}$ double spike was used to correct the isotopic ratios from the artificial isotopic fractionations. The $\delta^{56} \mathrm{Fe}$ values were calculated relative to the average of IRMM-14 reference material measurements bracketing each sample. The internal precision of each measurement is given

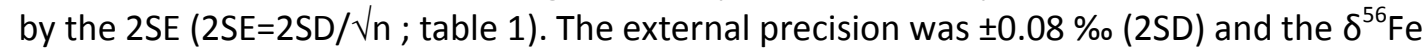
measurements were unbiased. The general performances of this method including the validation steps and the precision calculations are detailed in Lacan et al. (2010).

For this study, we performed several replicates of DFe samples at different steps of the processing (detailed in table 1). Three samples were split into duplicates before the chemical processing and they reproduced to within $\pm 0.04 \%$ (2SD) on average. Also two samples were split into replicates after the chemical processing, just before the mass spectrometric analysis, and they reproduced to within $\pm 0.05 \%$ o (2SD) on average. We consider that the external precision of the MC-ICPMS measurement $( \pm 0.08 \%, 2 S D)$ best characterizes the measurement uncertainty, excepted two analyses showing $2 \mathrm{SE}$ greater than the external precision $(2 \mathrm{SE}= \pm 0.09 \%$ ) for which the uncertainty is the 2SE (see table 1).

The double spike method coupled with Neptune MC-ICPMS analysis provides a precise and accurate determination of the iron concentration in the sample. The mean discrepancy between replicates was $1.9 \%$ (maximum discrepancy of $6.6 \%$ ).

\section{Results of iron concentrations and $\delta^{56} \mathrm{Fe}$}

The dissolved iron concentrations range from 0.06 to $1.46 \mathrm{nM}$ whereas the particulate iron concentrations range from 0.41 to $32.19 \mathrm{nM}$ (see Figure $3 \mathrm{~B}$ and $\mathrm{C}$ and Table 1). Samples from the coastal station (28) display higher concentrations than samples from the open ocean station (14). At both stations, the PFe dominates the iron content.

At station 28, the DFe concentrations range from 0.45 (at $94 \mathrm{~m}$ ) to $1.46 \mathrm{nM}$ (at $800 \mathrm{~m}$ ). These values are lower than the DFe concentrations reported by Mackey et al. (2002), closer to the PNG coast in the upper $150 \mathrm{~m}$ layer (between 1.3 and $2.6 \mathrm{nM}$ ). The surface sample shows a local maximum of $0.89 \mathrm{nM}$ at the surface ( $40 \mathrm{~m}$ depth, in the vicinity of the chlorophyll maximum), also observed in the total acid soluble iron data in Mackey et al. (2002) and Slemons et al (2010). At station 14 (open ocean), the DFe concentrations are very low in the upper $100 \mathrm{~m}$ layer $(0.06 \mathrm{nM})$, then increase sharply up to $0.5 \mathrm{nM}$ at $200 \mathrm{~m}$ depth and remains almost constant down to $800 \mathrm{~m}$ depth between 0.5 and $0.6 \mathrm{nM}$. This range is commonly observed in the open ocean (e.g., Johnson et al., 1997; de Baar and de Jong, 2001) and is in very good agreement with the few historical data available in the 
equatorial Pacific for depths shallower than $350 \mathrm{~m}$, i.e., at $140^{\circ} \mathrm{W}$ (Coale et al., 1996) and at $90^{\circ} \mathrm{W}$ (Gordon et al., 1998). The PFe concentration profile displays a vertical maximum at $198 \mathrm{~m}$ in the lower part of the EUC, also observed by Slemons et al. (2010). Both present profiles have lower DFe concentration than those of Slemons et al. (2010). The later range from 0.3 to $1.3 \mathrm{nM}$ and 0.3 to $4.2 \mathrm{nM}$ at Station 14 and 28 respectively and were obtained by Flow Injection Analysis in similar samples (from the same cruise and the same location but collected from different casts and acidified immediately).

Fe isotope compositions are displayed as function of potential density $\left(\sigma_{\theta}\right)$ in Figure $3 \mathrm{~A}$. Both fractions show positive values of $\delta^{56} \mathrm{Fe}$ (except one sample). They range from 0.01 to $0.58 \%$ in the dissolved fraction and from -0.02 to $0.46 \%$ in the particulate fraction. Taken as a whole, the $\delta^{56} \mathrm{Fe}$ data show largest variations in the vertical and not in the horizontal direction.

\section{Discussion}

Almost all the $\delta^{56} \mathrm{Fe}$ values are positive. Since, there is no direct marine iron source with a strong positive signature, positive $\delta^{56} \mathrm{Fe}$ in the seawater may be the result of fractionating processes. Considering the largest isotopic fractionations occur during redox reactions (e.g., Johnson et al., 2008), the small $\delta^{56} \mathrm{Fe}$ variations observed in this study suggest the redox conversion is only of minor importance for water column processes.

\subsection{Papua New Guinea area (station 28):}

The coastal station (St. 28) is located about $30 \mathrm{~km}$ from the PNG coast, in the currents from the southeast carrying waters from 0 to $1000 \mathrm{~m}$ of south Pacific origin equatorwards (Tsuchiya, 1991 ; Fine et al., 1994 ; Tsuchiya and Talley, 1996 ; Maes et al., 2007). Most of these waters have crossed the Vitiaz Strait via the New Guinea Coastal Undercurrent (NGCU ; Butt and Lindstrom, 1994 ; Fiedler and Talley, 2006) as shown in Figure 1.

High iron content of seawaters observed in all samples from station 28 (Figure 3B and C) may reflect local inputs of iron since the stabilized concentrations found in the open ocean rarely reach 1nM (e.g., Johnson et al. 1997 ; de Baar and de Jong, 2001). Indeed the northern PNG area is known to be subjected to significant local inputs of iron (e.g., Mackey et al., 2002). Isotopic compositions of dissolved Nd in seawater suggested that dissolution of PNG shelf sediments could account for the lithogenic enrichment of the oceanic waters from the surface down to $800 \mathrm{~m}$ depth (Lacan and Jeandel, 2001). Total dissolvable Fe data in the Bismarck Sea show that the Fe concentrations within NGCU increase along the northern coast of PNG and suggest that this Fe maybe mainly supplied by slope sediments (Mackey et al., 2002; Slemons et al., 2010). The sediments being abundantly deposited on the shelf and slope by the local rivers (notably the Sepik river, located upstream of the station 28; see Figure 1; Milliman and Syvitski, 1992), the sedimentary source must be linked to the riverine inputs. Although other kinds of sources could be invoked in this area, these studies emphasize the dominant role played by sediment remobilization.

The $\delta^{56} \mathrm{Fe}$ data range from 0.06 to $0.53 \pm 0.08 \%$ (2SD) in the DFe and from $-0.02 \pm 0.09 \%$ to $0.29 \%$ in the PFe. The PFe accounts for $\sim 90 \%$ of the iron content. In each sample, the DFe shows higher $\delta^{56} \mathrm{Fe}$ than the PFe. Such DFe values are not consistent with the negative signature presupposed for the sedimentary source. As reported in the introduction, the sediments were found to release DFe with $\delta^{56} \mathrm{Fe}$ from -3.3 to $-1.7 \%$ (Severmann et al., 2006; Homoky et al., 2009). These reported values, measured in three locations characterized by high organic carbon accumulation rates, reflect the process of bacterial dissimilatory iron reduction (DIR) within the reductive sediment and the intense redox-recycling at the interface (Severmann et al., 2006, 2010 ; Homoky et al., 2009). Thus, the positive $\delta^{56} \mathrm{DFe}$ measured in the water column of station 28 do not suggest a significant DIR 
source contribution and may involved another kind of sedimentary iron release. Although the most studied sedimentary input of iron is the one associated with bacterial reduction, the direct dissolution of sediment in oxic seawater also release dissolved elements (Jeandel et al., submitted ; Jones et al., submitted). Leaching experiments of sediments (in $0.5 \mathrm{M} \mathrm{HCl}$ ) from the northern PNG slope, sampled between 0 and $1200 \mathrm{~m}$ depth, displays a mean $\delta^{56} \mathrm{Fe}$ value of $+0.30 \pm 0.15 \%$ o $2 \mathrm{SD}$ (compared to a mean initial $\delta^{56} \mathrm{Fe}$ of $+0.01 \pm 0.18 \%$ o 2SD; Murray et al., 2010). These values matches very closely the dissolved values measured in the water column of station $28(+0.34 \pm 0.36 \%$ o $2 S D$, averaged over the whole water column). Taken together, these arguments suggest that the process releasing iron from the sediments could be a non reductive dissolution of the sediments rather than the DIR process. The local strong currents along the shelf may maintain oxic conditions in the surface layer of the sediments and limit the impact of DIR on the water column. Moreover, very large river sediment discharges and re-suspension of solid sediments occurring along the PNG coast (e.g., Kineke et al., 2000) would favor contact between the oxic seawater and the sediments. The transmissometry profile (see Figure 5 in Slemons et al., 2010) shows turbid layers at station 28, especially between depths of 300 and $700 \mathrm{~m}$, reflecting sediment re-suspension. This context, i.e., good oxygenation and resuspension of sediments, would favor such non reductive dissolution of sediment to the seawater rather than DIR.

The vertical $\delta^{56} \mathrm{Fe}$ heterogeneity at station 28 is difficult to interpret since the $\delta^{56} \mathrm{Fe}$ of the upstream waters are unknown. Nevertheless, some hypotheses can be proposed. The surface sample $(40 \mathrm{~m})$ shows a vertical maximum, especially in the particle fraction (up to $32 \mathrm{nM}$ ). In addition to sediment remobilisation, iron inputs from aerosol and from rivers have to be considered for the surface layer. Based on $\mathrm{Mn}$ and $\mathrm{Al}$ data and modeling, dust deposition has been suggested to be possibly responsible for the high concentrations found above $100 \mathrm{~m}$ (Slemons et al., 2010). The $\delta^{56} \mathrm{DFe}$ of $+0.53 \%$ at $40 \mathrm{~m}$ depth is, among all the samples of station 28 , the most different from the range characterizing solid aerosols (from $-0.03 \%$ to $0.24 \% \pm 0.08 \%$ o $2 \mathrm{SD}$ observed in dusts, loess and continental aerosols ; Beard et al., 2003b; Waeles et al., 2007). Assuming the soluble iron derived from solid aerosols display a similar signature (Waeles et al., 2007), the $\delta^{56} \mathrm{DFe}$ at $40 \mathrm{~m}$ suggests that atmospheric iron inputs to the surface waters of this area are not significant. Based on Rare Earth Element patterns, river input of dissolved material from the northern PNG coast has been suggested to be responsible for about a fifth of the lithogenic inputs to the undercurrents of the Bismarck Archipelago (Sholkovitz et al., 1999). Station 28, being downstream of the Sepik River, the $\delta^{56} \mathrm{DFe}$ in surface may also correspond to a riverine $\delta^{56} \mathrm{DFe}$ signature (Bergquist and Boyle, 2006 ; De Jong et al., 2007).

At $800 \mathrm{~m}$ depth, in the core of the AAIW, the $\delta^{56} \mathrm{Fe}$ is the lowest of the profile, with a value of $+0.06 \%$ in DFe and $-0.02 \%$ in PFe. These low $\delta^{56} \mathrm{PFe}$ particles may be re-suspended from initially low $\delta^{56} \mathrm{Fe}$ sediments (e.g. Yamaguchi et al., 2005) or may originate from hydrothermal activity (Rouxel et al. 2008). Actually there are numerous shallow ridges in the Bismarck Sea (e.g., Wells et al., 1999). Assuming the bulk of the DFe is released by a non reductive dissolution of the suspended particles within the seawater, the low $\delta^{56} \mathrm{PFe}$ could explain the low $\delta^{56} \mathrm{DFe}$ observed. Moreover the DFe concentration of $1.46 \mathrm{nM}$ at $800 \mathrm{~m}$ suggests an input of DFe in this layer. Such low $\delta^{56} \mathrm{DFe}$ source could be the hydrothermal activity (Sharma et al., 2001; Beard et al., 2003b; Rouxel et al., 2008).

Finally, the dominant source of iron to seawater in the PNG area is most likely a non reductive dissolution of iron from re-suspended sediments of the PNG margin. Because a contribution of other sources can not be completely rejected in surface and in the deep layer, we use the thermocline samples to characterize this new sedimentary signature. These samples display a DFe signature of $+0.37 \%$ on average $( \pm 0.15 \%, 2 S D, n=3)$. Assuming the steady state of the $\delta^{56} \mathrm{PFe}$ in these samples (due to a large excess of PFe as a reactant) and that all DFe is released by the non reductive dissolution of the present suspended particles $\left(\Delta^{56} \mathrm{Fe}_{\mathrm{DFe}-\mathrm{PFe}}\right.$ would correspond to the subtraction of $\delta^{56} \mathrm{DFe}$ and $\left.\delta^{56} \mathrm{PFe}\right)$, we deduce that this process create an isotopic fractionation of $\Delta^{56} \mathrm{Fe}_{\mathrm{DFe}-\mathrm{PFe}}=$ $+0.20 \%$ on average $( \pm 0.11 \%$ o, $2 S D, n=2)$. Such process may partly explain the positive $\delta^{56} \mathrm{DFe}$ signature found in this study. 


\subsection{Thermocline waters in the EUC}

The EUC is a strong eastward flowing current which cross the whole Pacific Ocean along the equator. It is centered in the pycnocline (between 100 and 300m depth, becoming shallower eastwards) with a maximum velocity around $1 \mathrm{~m} / \mathrm{s}$ (Wyrtki and Kilonsky, 1984). NGCU carries thermocline waters to the equator and constitutes the main source of waters to EUC at its western end (see Figure 1; Tsuchiya et al., 1989). As suggest by Goodman et al. (2005), over 2/3 of EUC waters at $140^{\circ} \mathrm{W}$ may be of southern origin.

As shown in Figure 2A, the samples from 140 and $198 \mathrm{~m}$ at station 14 correspond to the same water masses as the samples from 191 and $321 \mathrm{~m}$ at station 28 respectively, the SPEW and the $13 \mathrm{CW}$ respectively. Thus these water masses were sampled twice at two locations along their route between the PNG area and the central Pacific, being first carried by the NGCU and then by the EUC.

The $\delta^{56} \mathrm{DFe}$ of both water masses remain almost unchanged between stations 28 and 14 (figure $3 \mathrm{~A}$ and table 1): $\delta^{56} \mathrm{Fe}=0.29$ and $0.40 \pm 0,08 \%$ (2SD) for the $13 \mathrm{CW}$, and $\delta^{56} \mathrm{Fe}=0.43$ and $0.31 \pm 0,08 \%$ o (2SD) for the SPEW, respectively. That is also the case for the $\delta^{56} \mathrm{PFe}$. The constancy of the $\delta^{56} \mathrm{Fe}$ suggests that i) the Fe found in the EUC in the central Pacific is the same than the iron found in the PNG area, and thus the PNG is the source of iron to EUC, as already suggested by earlier studies (Lacan and Jeandel, 2001 ; Mackey et al., 2002 ; Slemons et al., 2010), and ii) that the iron isotopic signature has been preserved in the EUC. Consequently, we suggest that the PFe in the EUC at $0^{\circ} \mathrm{N}, 180^{\circ} \mathrm{E}$ is a residue of sediments initially re-suspended near the PNG margin while the DFe content is the result of a non reductive dissolution of these sediments.

Along this flow, a removal of iron is observed between stations 28 and 14. While the upper part of the EUC (carrying the SPEW) have been abundantly renewed due to equatorial upwelling, the lower part of the EUC (carrying the $13 \mathrm{CW}$ ) is not significantly diluted along the route (Tsushiya et al., 1989) and allows observing the effect of the removal process on the $\delta^{56} \mathrm{Fe}$. Assuming that the $13 \mathrm{CW}$ sampled at station 28 is the source of the $13 \mathrm{CW}$ in the lower EUC at station 14, the most likely process which removes $31 \%$ of DFe (from 0.77 to $0.54 \mathrm{nM}$ ) would be the adsorption of DFe on the settling particle surface (scavenging ; Slemons et al., in press). Because the $\delta^{56} \mathrm{DFe}$ difference between both locations is not significant, such removal seems not to fractionate iron isotopes. To further constrain this process, we estimated its isotopic fractionation. The isotopic fractionation (assumed to be constant) between removed DFe and DFe in the seawater is defined by:

$$
\Delta^{56} \mathrm{Fe}_{\text {rem } D F e-S W D F e}=\delta^{56} \mathrm{Fe}_{i-\text { rem } D F e}^{f}-\delta^{56} \mathrm{Fe} e_{S W D F e}^{f}
$$

where $f$ is the fraction of DFe remaining in the water relative to the initial DFe concentration (69\% in the present case); $\delta^{56} \mathrm{Fe}_{i-\mathrm{rem} D \mathrm{DF}}^{f}$ and $\delta^{56} \mathrm{Fe}_{S W D F e}^{f}$ are the $\delta^{56} \mathrm{Fe}$ values of the instantaneous product of the removal process (i.e. of the DFe removed in an infinitely short time) and of the DFe remaining in the seawater respectively, for a given $f$ value. Assuming a Rayleigh fractionation, equation 2 quantifies the isotopic fractionation associated with the DFe removal, as a function of the difference between the initial $\delta^{56} \mathrm{DFe}$ of the seawater $\left(\delta^{56} \mathrm{Fe}{ }_{S W D F e}^{f=1}\right)$ and the $\delta^{56} \mathrm{DFe}$ of the seawater at a given $\mathrm{f}$ $\left(\delta^{56} \mathrm{Fe}{ }_{S W D F e}^{f}\right)$.

$$
\Delta^{56} \mathrm{Fe}_{\text {rem DFe }-S W D F e} \approx\left(\delta^{56} \mathrm{Fe}_{S W D F e}^{f}-\delta^{56} \mathrm{Fe}_{S W D F e}^{f=1}\right) / \ln (f)
$$

Equation 2 lead to an isotopic fractionation of $\Delta^{56} \mathrm{Fe}_{\text {rem DFe-SW DFe }}=-0.30 \pm 0.31 \%$ (2SD). Although the large uncertainty does not allow a confident interpretation of the fractionation direction, this estimation show that if there is an isotopic fractionation associated with scavenging of DFe from the water column, it is rather small.

In addition, $82 \%$ of the PFe is removed between station 28 and station 14, most likely by aggregation and settling of particles. As for the DFe removal, the resulting change of $\delta^{56} \mathrm{PFe}$ is not 
significant. This corresponds to a potential isotopic fractionation such as $\Delta^{56} \mathrm{Fe}_{\text {rem PFe-sW PFe }}=$ $-0.05 \pm 0.07 \%$ o (2SD ; as proceed for the DFe with Equation 2 ). This very small value is not surprising since one does not expect significant isotopic fractionation associated with such mechanisms.

\subsection{Antarctic Intermediate Water (AAIW)}

The AAIW reaches the equator from the South Pacific, carried by the intermediate NGCU via the PNG area (Tsuchiya, 1991; Tsuchiya and Talley, 1996). The isotopic composition of neodymium, that can be used to trace water mass pathways, also suggests that the AAIW found along the equator comes from the PNG area (Lacan and Jeandel, 2001). It will therefore be assumed in the following that the AAIW of station 28 is the source of the AAIW of station 14. The similarities of the potential temperatures and salinities of the AAIW from stations 28 and 14 support this assumption (Table 1 and Figure 2).

The DFe concentration in the AAIW decreases significantly from $1.46 \mathrm{nM}$ at station 28 to $0.60 \mathrm{nM}$ at station 14 (Table 1). This corresponds to a $60 \%$ removal of the dissolved iron content. Despite this large iron removal, the $\delta^{56} \mathrm{DFe}$ remains nearly constant, varying from $0.06 \pm 0.08 \%$ o (2SD) at station 28 to $0.22 \pm 0.08 \%$ o (2SD) at station 14. The difference of these 2 values is just significant and allows estimating the isotopic fractionation induced by the DFe removal. Equation 2 leads to $\Delta^{56} \mathrm{Fe}_{\text {rem DFe - SW DFe }}=-0.18 \pm 0.12 \%$ (2SD). Such isotopic fractionation is very low and is consistent with the $\Delta^{56} \mathrm{Fe}_{\text {rem DFe-sW DFe }}$ estimated in the $13 \mathrm{CW}$. This negative value means that the process would favor the removal of light iron isotopes. Assuming that such fractionation is induced by adsorption of DFe onto particles, this is not coherent with the $\Delta^{56} \mathrm{Fe}_{\mathrm{fe}(I) \text { adsorb-Fe(II)aq }}$ of $+0,3$ to $+0,9 \%$ observed by Crosby et al. (2007) during in vitro experiments. This discrepancy is likely due to the contrasted conditions occurring in the Crosby et al. experiment compared with seawater : different iron forms are involved (mainly $\mathrm{Fe}(\mathrm{III})$ in seawater rather than $\mathrm{Fe}(\mathrm{II})$ in the in vitro experiment) and organic ligands may strongly interact with adsorption process in seawater.

As for DFe, there is a major PFe removal (95\%) between station 28 and station 14 in the AAIW. This removal, likely due to aggregation and settling of particles, accounts for an isotopic fractionation of $\Delta^{56} \mathrm{Fe}_{\text {rem PFe - SW PFe }}=-0.10 \pm 0.04 \%$ (2SD; according equation 2). This value is consistent

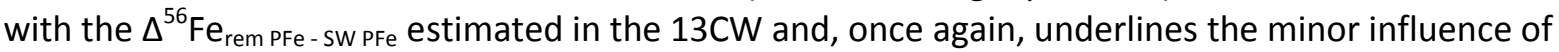
the PFe removal on the $\delta^{56} \mathrm{PFe}$ signature.

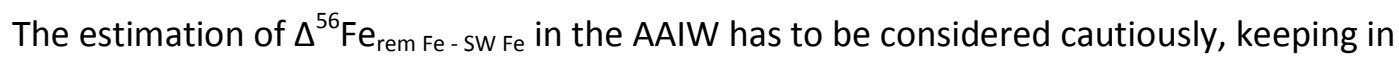
mind the scarcity of the data and the assumptions involved. First, it assumes the removal is the only process undergone by the Fe between station 28 and 14 in the AAIW, which is not obvious for the DFe. Actually the dissolved oxygen profiles (Figure 2B) show that the oxygen content of the AAIW decreases significantly between these two locations, and suggests that significant bacterial remineralization occurred during the transit of the AAIW (mixing is neglected). The fractionation relative to the removal of DFe expressed here is valid only if the remineralization occurring in the water column does not affect the iron isotopes in the DFe. Moreover the contribution from additional iron sources along the route of the EUC cannot be excluded and could possibly explain the increase of $\delta^{56} \mathrm{PFe}$ between stations 28 and 14 .

\subsection{Biological uptake in the central equatorial Pacific $\left(0^{\circ} \mathrm{N}, 180^{\circ} \mathrm{E}\right.$, station 14)}

The surface waters at station 14 are fed by the equatorial upwelling and the westward flow of the South Equatorial Current (SEC ; Wyrtki and Kilonsky, 1984). The surface waters at station 14 display low DFe concentrations $(0.06 \mathrm{nM})$. The flux of total iron from aerosols to the surface ocean was quantified during the cruise and found to be extremely low in this area (Shank and Johansen, 2008). In addition the $\delta^{56} \mathrm{DFe}$ of the subsurface water $(0.58 \%$ at $99 \mathrm{~m}$ depth) is significantly different from the assumed atmospheric signature, $0.1 \%$ (Beard et al., 2003b; Waeles et al., 2007). 
The seawater at $99 \mathrm{~m}$ was sampled in the chlorophyll maximum as indicated by the fluorescence profile (Figure 4). Such a sample therefore reflects the impact of the biological uptake on the $\delta^{56} \mathrm{Fe}$ of the surrounding seawater. This sample displays a DFe concentration of $0.06 \mathrm{nM}$ and a $\delta^{56} \mathrm{DFe}$ of $0.58 \%$ o (Table 1 ). The hydrographic parameters suggest this seawater is the result of vertical mixing between the above and underlying waters. From the salinity data (we chose the salinity which is more conservative than the temperature in surface waters at the equator, see table 1 and Figure 2) we estimate that this seawater is a mixture of $83 \%$ of the underlying water (SPEW at $140 \mathrm{~m}$, of which DFe concentration is $0.20 \mathrm{nM}$ and $\delta^{56} \mathrm{DFe}$ is $0.31 \%$ ), and $17 \%$ of the overlying water, (of which DFe concentration is $0.06 \mathrm{nM}$ and $\delta^{56} \mathrm{DFe}$ is unknown). Assuming that the mixing conserves the DFe content, it would yield a DFe concentration of $0.18 \mathrm{nM}$ at $99 \mathrm{~m}$ (before any biological consumption), of which $96 \%$ would come from the SPEW and $4 \%$ from the surface layer. Therefore we assume that the $\delta^{56} \mathrm{Fe}$ resulting from the mixing is the same as that in the SPEW $(0.31 \%$ ). Comparison of the DFe concentration resulting from the mixing $(0.18 \mathrm{nM})$ with the DFe concentration observed in the $99 \mathrm{~m}$ sample $(0.06 \mathrm{nM})$ suggests that there is a DFe removal of $0.12 \mathrm{nM}$ (two third of the initial content). Because $99 \mathrm{~m}$ corresponds to the chlorophyll maximum location, we assume that the DFe removal is exclusively due to biological uptake. The biological uptake appears to be associated with an isotopic fractionation, as suggested by the difference of $\delta^{56} \mathrm{DFe}$ between the upwelled SPEW water at open ocean station $14(0,31 \%)$ and the measured surface water at the same station $(0.58 \% \circ)$. Assuming steady state and that this uptake follows a Rayleigh fractionation, equation 2 leads to an isotopic fractionation of $\Delta^{56} \mathrm{Fe}_{\text {phyto-sw DFe }}=-0.25 \pm 0.10 \%$ o (2SD).

Assuming all the particles at $99 \mathrm{~m}$ are phytoplankton organisms, the isotopic fractionation associated with the biological uptake can also be estimated using the PFe. According a Rayleigh distillation model, the PFe can be considered either as an instantaneous product or as a total product. Assuming the phytoplankton is not removed from the $99 \mathrm{~m}$ layer, PFe would correspond to the total product. Its isotopic composition $\left(\delta^{56} \mathrm{Fe}_{\text {phyto }-t o t}^{f}\right)$ is defined in equation 3.

$$
\Delta^{56} \mathrm{Fe}_{\text {phyto }-S W D F e} \approx\left(\delta^{56} \mathrm{Fe}_{S W D F e}^{f}-\delta^{56} \mathrm{Fe} e_{\text {phyto }- \text { tot }}^{f}\right) \frac{(1-f)}{\ln (f)}
$$

Equation 3 leads to a $\Delta^{56} \mathrm{Fe}$ phyo-SW DFe of $-0.08 \pm 0.07 \%$ (2SD). Although the upwelling tends to decrease the flux of settling particles, it appears unrealistic to totally neglect this flux and to consider the PFe as the total product. Assuming the phytoplankton is consistently removed from the $99 \mathrm{~m}$ layer, PFe would correspond to the instantaneous product assimilated by the phytoplankton (for a very short time). In this case, the isotopic fractionation is the difference between the $\delta^{56} \mathrm{PFe}$ and the $\delta^{56} \mathrm{DFe}$ and corresponds to a $\Delta^{56} \mathrm{Fe}$ phyto-SW DFe of $-0.13 \pm 0.11 \%$ (2SD). This is consistent with the value deduced from the evolution of the DFe pool $(-0.25 \pm 0.10 \%$ o). These isotopic fractionations are small and reflect that phytoplankton would favor the uptake of light iron isotopes and that the surrounding waters would get heavier as they get depleted. These values are also in agreement with the range of $\left|\Delta^{56} \mathrm{Fe}_{\text {phyto-DFe }}\right|<0.32 \%$, deduced from natural seawater samples in the southern Atlantic Ocean (Lacan et al., 2008), and with observations of isotope fractionation during Fe uptake by higher plants (Guelke and Von Blanckenburg, 2007). With a better constrained isotopic fractionation induced by the phytoplankton uptake in seawater, the use of $\delta^{56} \mathrm{Fe}$ in a Rayleigh distillation model will allow quantifying the flux of settling particles.

\section{Conclusion}

These $\delta^{56} \mathrm{Fe}$ measurements constitute the first substantial dataset of this kind in the ocean. They come from two mid-depth profiles in the western and central equatorial Pacific Ocean. They range from +0.01 to $+0.58 \%$ for DFe and from -0.02 to $+0.46 \%$ for PFe. The average measurement uncertainty of $\pm 0.08 \%$ o (2SD) allows observing significant variations within these ranges. This 
uncertainty is only $3 \%$ of the whole range of variations observed in seawater so far (from -1.82 to $+0.71 \%$, John and Adkins, 2010), which suggests that the isotopic composition of the Fe dissolved in seawater constitutes a new sensitive tracer of the oceanic iron cycle. In particular, these data provide new information about the iron sources and cycle in the equatorial Pacific Ocean. The small $\delta^{56} \mathrm{Fe}$ variations observed in this study suggest the redox conversion is only of minor importance for water column processes. The largest $\delta^{56} \mathrm{Fe}$ variations occur in the vertical and not in the horizontal direction. Each water mass appears to have its own isotope composition that is preserved over long distances.

Off Papua New Guinea $\left(3^{\circ} \mathrm{S}, 144^{\circ} \mathrm{E}\right)$, where the dominant iron source is the margin sediments, the positive $\delta^{56} \mathrm{Fe}$ of the dissolved fraction (from $+0.06 \%$ o to $+0.53 \%$ ) indicates that iron is not produced by dissimilatory iron reduction (characterized by a very negative $\delta^{56} \mathrm{Fe}$ ) but might be released by the non reductive dissolution of sediment particles in seawater. The high sediment discharge from local rivers and the flow of strong western boundary currents along the northern coast of Papua New Guinea may remobilize the sediments and favor such dissolution. A distinct iron isotope signature is found to characterize this sedimentary source : a $\delta^{56} \mathrm{DFe}$ of $+0.37 \pm 0.15 \%$ o (2SD, $\mathrm{n}=3)$ and a $\Delta^{56} \mathrm{Fe}_{\mathrm{DFe}-\mathrm{PFe}}=+0.20 \pm 0.11 \%$ o $(2 \mathrm{SD}, \mathrm{n}=2)$ as displayed in the thermocline waters near PNG. The general positive trend of the data set emphasizes the role of the non-reductive dissolution of sediments in the marine iron isotope cycle. Because there is no evidence of atmospheric, hydrothermal and direct riverine Fe inputs in our samples, we did not inform their isotopic signature. An overview of the marine iron isotope cycle, from elements of literature and finding of this study, is proposed in Figure 5.

The hydrodynamic study of the region suggests that the station 28 (off PNG) might be considered as the main source of intermediate and thermocline waters to the station $14\left(0^{\circ} \mathrm{N}, 180^{\circ} \mathrm{E}\right)$. Especially for the thermocline waters carried into the EUC, the $\delta^{56} \mathrm{Fe}$ signatures remain unchanged between these two stations, which suggests the DFe found at $0^{\circ} \mathrm{N}, 180^{\circ} \mathrm{E}$ originates from the Papua New Guinea area and furthermore from the non reductive dissolution of the shelf sediments. This confirms that the iron feeding the eastern high nutrient low chlorophyll area would originate from PNG.

The dissolved and particulate Fe concentrations are found to decrease between the coastal PNG station and the dateline. Assuming that the former station is the source of the waters found at the latter station, isotopic fractionations associated with such Fe removal were assessed. They all display small values of $\Delta^{56} \mathrm{Fe}_{\text {removed-sw Fe }}:-0.30 \pm 0.31 \%$ o to $-0.18 \pm 0.12 \%$ or scavenging of DFe (2SD) and of $-0.10 \pm 0.04 \%$ o to $-0.05 \pm 0.31 \%$ o (2SD) for aggregation / settling of particles. The isotopic fractionation associated with phytoplankton uptake, estimated at station $14\left(0^{\circ} \mathrm{N}, 180^{\circ} \mathrm{E}\right)$ in the fluorescence maximum, is found to be characterized by $\Delta^{56} \mathrm{Fe}_{\text {phyto-DFe }}=-0.25 \pm 0.10 \%$ o to $-0.13 \pm 0.11 \%$ o (2SD). Phytoplankton would slightly favor the uptake of light iron, thereby making the DFe pool heavier. These estimations have to be considered cautiously and need to be further constrained. The limited extent of these fractionations within the water column may facilitate the use of iron isotopes as a tracer of DFe sources in the ocean.

This first study illustrates the powerful potential of the Fe isotope composition in seawater as a new tracer of the oceanic Fe cycle. In order to improve our understanding of this new tracer, we need to continue documenting the $\delta^{56} \mathrm{Fe}$ in the ocean and in the iron sources, and to identify phase exchange processes which fractionate iron isotopes in the water column (from measurements of the dissolved and particulate phases in realistic oceanic condition). The multi-tracer approach should be especially helpful to inform the behavior of the iron isotopes in seawater.

\section{Acknowledgements}


The CNRS (French National Center for Scientific Research) is thanked for supporting this study. Comments of $\mathrm{C}$. Jeandel, F. Poitrasson and an anonymous reviewer have greatly helped improve this manuscript. We greatly appreciate the efforts of the captain and crew of the Kilo Moana, and of marine technicians G. Foreman and D. Fitzgerald. C. Venchiarutti, O. Yigiterhan, J. Resing are thanked for their help with the sampling, and P. Dutrieux for his educational explanations about the local flows. We are grateful to L. Slemons, S. Severmann and J. McManus for having communicated unpublished data that helped the understanding of this dataset. We thank J. Chmeleff, for his efforts to achieve the analysis despite the Neptune breakdowns, M. Grenier, for having supplied relevant retrotrajectories in the region, and also Kathy and Sarah for their everyday support during this study.

\section{References}

de Baar, H., de Jong, J., 2001. Distributions, sources and sinks of iron in seawater, dans: The biogeochemistry of iron in seawater, IUPAC Series on Analytical and Physical Chemistry of Environmental Systems. D. Turner and K. Hunter, Chichester, p. pp. 123-253.

Beard, B., Johnson, C., 2004. Fe isotope variations in the modern and ancient earth and other planetary bodies. Rev. Mineral. Geochem. 55, 319-357.

Beard, B., Johnson, C., Skulan, J., Nealson, K., Cox, L., Sun, H., 2003a. Application of Fe isotopes to tracing the geochemical and biological cycling of Fe. Chemical Geology 195, 87-117.

Beard, B., Johnson, C., Von Damm, K., Poulson, R., 2003b. Iron isotope constraints on Fe cycling and mass balance in oxygenated Earth oceans. Geology 31, 629-632.

Behrenfeld, M., Bale, A., Kolber, Z., Aiken, J., Falkowski, P., 1996. Confirmation of iron limitation of phytoplankton photosynthesis in the equatorial Pacific Ocean. Nature 383, 508-511.

Bergquist, B., Boyle, E., 2006. Iron isotopes in the Amazon River system: Weathering and transport signatures. Earth Planet. Sci. Lett. 248, 54-68.

Boyd, P., Jickells, T., Law, C., Blain, S., Boyle, E., Buesseler, K., Coale, K., Cullen, J., de Baar, H., Follows, M., Harvey, M., Lancelot, C., Levasseur, M., Owens, N., Pollard, R., Rivkin, R., Sarmiento, J., Schoemann, V., Smetacek, V., Takeda, S., Tsuda, A., Turner, S., Watson, A., 2007. Mesoscale iron enrichment experiments 1993-2005: Synthesis and future directions. Science 315, 612617.

Bullen, T., White, A., Childs, C., Vivit, D., Schulz, M., 2001. Demonstration of significant abiotic iron isotope fractionation in nature. Geology 29, 699-702.

Butt, J., Lindstrom, E., 1994. Currents Off the East-Coast of New-Ireland, Papua-New-Guinea, and Their Relevance to Regional Undercurrents in the Western Equatorial Pacific-Ocean. J. Geophys. Res.-Oceans 99, 12503-12514.

Coale, K., Fitzwater, S., Gordon, R., Johnson, K., Barber, R., 1996. Control of community growth and export production by upwelled iron in the equatorial Pacific Ocean. Nature 379, 621-624.

Crosby, H., Roden, E., Johnson, C., Beard, B., 2007. The mechanisms of iron isotope fractionation produced during dissimilatory Fe(III) reduction by Shewanella putrefaciens and Geobacter sulfurreducens. Geobiology 5, 169-189.

Dideriksen, K., Baker, J., Stipp, S., 2008. Equilibrium Fe isotope fractionation between inorganic aqueous $\mathrm{Fe}(\mathrm{III})$ and the siderophore complex, Fe(III)-desferrioxamine B. Earth Planet. Sci. 
Lett. 269, 280-290.

Elrod, V., Berelson, W., Coale, K., Johnson, K., 2004. The flux of iron from continental shelf sediments: A missing source for global budgets. Geophys. Res. Lett. 31.

Escoube, R., Rouxel, O., Sholkovitz, E., Donard, O., 2009. Iron isotope systematics in estuaries: The case of North River, Massachusetts (USA). Geochim. Cosmochim. Acta 73, 4045-4059.

Fiedler, P., Talley, L., 2006. Hydrography of the eastern tropical Pacific: A review. Prog. Oceanogr. 69, 143-180.

Fine, R., Lukas, R., Bingham, F., Warner, M., Gammon, R., 1994. The Western Equatorial Pacific - a Water Mass Crossroads. J. Geophys. Res.-Oceans 99, 25063-25080.

Goodman, P., Hazeleger, W., De Vries, P., Cane, M., 2005. Pathways into the Pacific Equatorial Undercurrent: A trajectory analysis. J. Phys. Oceanogr. 35, 2134-2151.

Gordon, R., Johnson, K., Coale, K., 1998. The behaviour of iron and other trace elements during the IronEx-I and PlumEx experiments in the Equatorial Pacific. Deep Sea Res. II 45, 995-1041.

Guelke, M., Von Blanckenburg, F., 2007. Fractionation of stable iron isotopes in higher plants. Environ. Sci. Technol. 41, 1896-1901.

Homoky, W., Severmann, S., Mills, R., Statham, P., Fones, G., 2009. Pore-fluid Fe isotopes reflect the extent of benthic Fe redox recycling: Evidence from continental shelf and deep-sea sediments. Geology 37, 751-754.

Ingri, J., Malinovsky, D., Rodushkin, I., Baxter, D., Widerlund, A., Andersson, P., Gustafsson, O., Forsling, W., Ohlander, B., 2006. Iron isotope fractionation in river colloidal matter. Earth and Planetary Science Letters 245, 792-798.

Jeandel, C., Peucker-Ehrenbrink, B., Godderis, Y., Lacan, F., Aumont, O., Arsouze, T., submitted. Ocean margin processes affect biogeochemical cycles of climate-relevant elements $\mathrm{Si}, \mathrm{Ca} \mathrm{Mg}$ and Fe. J. Earth and Planetary Science Letters.

Jickells, T., An, Z., Andersen, K., Baker, A., Bergametti, G., Brooks, N., Cao, J., Boyd, P., Duce, R., Hunter, K., Kawahata, H., Kubilay, N., laRoche, J., Liss, P., Mahowald, N., Prospero, J., Ridgwell, A., Tegen, I., Torres, R., 2005. Global iron connections between desert dust, ocean biogeochemistry, and climate. Science 308, 67-71.

John, S., Adkins, J., 2010. Analysis of dissolved iron isotopes in seawater. Mar. Chem. 119, 65-76.

Johnson, C., Beard, B., Roden, E., 2008. The iron isotope fingerprints of redox and biogeochemical cycling in the modern and ancient Earth. Annu. Rev. Earth Planet. Sci. 36, 457-493.

Johnson, K., Gordon, R., Coale, K., 1997. What controls dissolved iron concentrations in the world ocean? Mar. Chem. 57, 137-161.

Jones, M., Pearce, C., Jeandel, C., Eiriksdottir, E., Gislason, S., Oelkers, E., submitted. Can riverine particulate material dissolution close the global strontium cycle? Nature.

de Jong, J., Schoemann, V., Tison, J., Becquevort, S., Masson, F., Lannuzel, D., Petit, J., Chou, L., Weis, D., Mattielli, N., 2007. Precise measurement of Fe isotopes in marine samples by multicollector inductively coupled plasma mass spectrometry (MC-ICP-MS). Anal. Chim. Acta 589, 105-119. 
Kineke, G., Woolfe, K., Kuehl, S., Milliman, J., Dellapenna, T., Purdon, R., 2000. Sediment export from the Sepik River, Papua New Guinea: evidence for a divergent sediment plume. Cont. Shelf Res. 20, 2239-2266.

Kohfeld, K., Le Quere, C., Harrison, S., Anderson, R., 2005. Role of marine biology in glacialinterglacial $\mathrm{CO}_{2}$ cycles. Science 308, 74-78.

Kuma, K., Nishioka, J., Matsunaga, K., 1996. Controls on iron(III) hydroxide solubility in seawater: The influence of pH and natural organic chelators. Limnology and Oceanography 41, 396-407.

Lacan, F., Jeandel, C., 2001. Tracing Papua New Guinea imprint on the central Equatorial Pacific Ocean using neodymium isotopic compositions and Rare Earth Element patterns. Earth Planet. Sci. Lett. 186, 497-512.

Lacan, F., Radic, A., Jeandel, C., Poitrasson, F., Sarthou, G., Pradoux, C., Freydier, R., 2008. Measurement of the isotopic composition of dissolved iron in the open ocean. Geophys. Res. Lett. 35.

Lacan, F., Radic, A., Jeandel, C., Poitrasson, F., Sarthou, G., Pradoux, C., Freydier, R., chmeleff, J., in press. High precision determination of the isotopic composition of dissolved iron in iron depleted seawater by double spike MC-ICPMS. Anal. Chem.

Lacan, F., Labatut, M., Radic, A., Jeandel, C., in preparation. Chemical composition of suspended particles in the Atlantic sector of the Southern Ocean.

Lam, P., Bishop, J., 2008. The continental margin is a key source of iron to the HNLC North Pacific Ocean. Geophys. Res. Lett. 35.

Lam, P., Bishop, J., Henning, C., Marcus, M., Waychunas, G., Fung, I., 2006. Wintertime phytoplankton bloom in the subarctic Pacific supported by continental margin iron. Global Biogeochem. Cycles 20.

Lukas, R., Firing, E., 1984. The Geostrophic Balance of the Pacific Equatorial Undercurrent. Deep Sea Res. I 31, 61-66.

Mackey, D., O'Sullivan, J., Watson, R., 2002. Iron in the western Pacific: a riverine or hydrothermal source for iron in the Equatorial Undercurrent? Deep Sea Res. I 49, 877-893.

Maes, C., Gourdeau, L., Couvelard, X., Ganachaud, A., 2007. What are the origins of the Antarctic Intermediate Waters transported by the North Caledonian Jet? Geophys. Res. Lett. 34.

Milliman, J., Syvitski, J., 1992. Geomorphic Tectonic Control of Sediment Discharge to the Ocean - the Importance of Small Mountainous Rivers. Journal of Geology 100, 525-544.

Moore, J., Braucher, O., 2008. Sedimentary and mineral dust sources of dissolved iron to the world ocean. Biogeosciences 5, 631-656.

Murray, J., Balistrieri, L., Paul, B., Nelson, B., Laydbak, J., Brunskill, G., 2010. $\delta^{56} \mathrm{Fe}$ in surface sediments from the northeast margin of Papua New Guinea as a tracer for the origin of iron to the equatorial undercurrent. EOS Trans. AGU 91, Ocean Sci. Meet. Suppl., Abstract PA35B03.

Poitrasson, F., 2006. On the iron isotope homogeneity level of the continental crust. Chemical Geology 235, 195-200.

Rouxel, O., Auro, M., 2010. Iron Isotope Variations in Coastal Seawater Determined by Multicollector 
ICP-MS. Geostandards and Geoanalytical Research 34, 135-144.

Rouxel, O., Shanks, W., Bach, W., Edwards, K., 2008. Integrated Fe- and S-isotope study of seafloor hydrothermal vents at East Pacific rise 9-10 degrees N. Chem. Geol. 252, 214-227.

Rue, E., Bruland, K., 1995. Complexation of Iron(III) by Natural Organic-Ligands in the Central North Pacific as Determined by a New Competitive Ligand Equilibration Adsorptive Cathodic Stripping Voltammetric Method. Marine Chemistry 50, 117-138.

Severmann, S., Johnson, C., Beard, B., McManus, J., 2006. The effect of early diagenesis on the Fe isotope compositions of porewaters and authigenic minerals in continental margin sediments. Geochim. Cosmochim. Acta 70, 2006-2022.

Severmann, S., McManus, J., Berelson, W., Hammond, D., 2010. The continental shelf benthic iron flux and its isotope composition. Geochim. Cosmochim. Acta 74, 3984-4004.

Shank, L., Johansen, A., 2008. Atmospheric trace metal and labile iron deposition fluxes to the equatorial Pacific during EUCFe2006. Ocean Sci. Meet.

Sharma, M., Polizzotto, M., Anbar, A., 2001. Iron isotopes in hot springs along the Juan de Fuca Ridge. Earth Planet. Sci. Lett. 194, 39-51.

Sholkovitz, E., Elderfield, H., Szymczak, R., Casey, K., 1999. Island weathering: river sources of rare earth elements to the Western Pacific Ocean. Mar. Chem. 68, 39-57.

Slemons, L., Gorgues, T., Aumont, O., Menkes, C., Murray, J.W., 2009. Biogeochemical impact of a model western iron source in the Pacific Equatorial Undercurrent. Deep Sea Res. I 56, 21152128.

Slemons, L., Murray, J., Resing, J., Paul, B., Dutrieux, P., 2010. Western Pacific coastal sources of iron, manganese, and aluminum to the Equatorial Undercurrent. Global Biogeochemical Cycles 24.

Slemons, L. , Murray, J.W., Gorgues, T., Aumont, O.,Menkes, C., in press. Retention and loss of upwelled nutrients in the equatorial Pacific Ocean: Nitrate, silicate, and iron cycling in a global biogeochemical model. Journal of Marine Research.

Tagliabue, A., Bopp, L., Aumont, O., 2009. Evaluating the importance of atmospheric and sedimentary iron sources to Southern Ocean biogeochemistry. Geophys. Res. Lett. 36.

Tagliabue, A., Bopp, L., Dutay, J., Bowie, A., Chever, F., Jean-Baptiste, P., Bucciarelli, E., Lannuzel, D., Remenyi, T., Sarthou, G., Aumont, O., Gehlen, M., Jeandel, C., 2010. Hydrothermal contribution to the oceanic dissolved iron inventory. Nat. Geosci. 3, 252-256.

Tomczak, M., Godfrey, J.S., 2003. Hydrology of the Pacific Ocean. In: Regional Oceanography: an Introduction, 2nd improved edition, Daya Publishing House, Delhi, pp. 137-156

Tsuchiya, M., 1991. Flow Path of the Antarctic Intermediate Water in the Western Equatorial SouthPacific Ocean. Deep Sea Res. II 38, S273-S279.

Tsuchiya, M., Lukas, R., Fine, R., Firing, E., Lindstrom, E., 1989. Source Waters of the Pacific Equatorial Undercurrent. Prog. Oceanogr. 23, 101-147.

Tsuchiya, M., Talley, L., 1996. Water-property distributions along an eastern Pacific hydrographic section at 135W. J. Mar. Res. 54, 541-564. 
Ussher, S., Achterberg, E., Worsfold, P., 2004. Marine Biogeochemistry of Iron. Environ. Chem. 1, 6780.

Waeles, M., Baker, A., Jickells, T., Hoogewerff, J., 2007. Global dust teleconnections: aerosol iron solubility and stable isotope composition. Environ. Chem. 4, 233-237.

Wells, M., Vallis, G., Silver, E., 1999. Tectonic processes in Papua New Guinea and past productivity in the eastern equatorial Pacific Ocean. Nature 398, 601-604.

Wiederhold, J., Kraemer, S., Teutsch, N., Borer, P., Halliday, A., Kretzschmar, R., 2006. Iron isotope fractionation during proton-promoted, ligand-controlled, and reductive dissolution of goethite. Environ. Sci. Technol. 40, 3787-3793.

Wyrtki, K., Kilonsky, B., 1984. Mean water and current structure during the Hawaii-to-Tahiti shuttle experiment. J. Phys. Oceanogr. 14, 242-254.

Yamaguchi, K., Johnson, C., Beard, B., Ohmoto, H., 2005. Biogeochemical cycling of iron in the Archean-Paleoproterozoic Earth: Constraints from iron isotope variations in sedimentary rocks from the Kaapvaal and Pilbara Cratons. Chemical Geology 218, 135-169. 
Table 1: Isotopic compositions and concentrations of dissolved and particulate Fe (from this study) and their corresponding sampling information and hydrographic parameters (from the EUCFe website, ) at station 14 and 28 of the EUCFe cruise (2006). The 2SE is the internal precision of each isotopic composition measurement (at the $95 \%$ confidence level). The measurement uncertainty is $\pm 0.08 \%$ ( 2 SD, at the $95 \%$ confidence level) or the 2 SE when the 2 SE is larger than $0.08 \%$.

\begin{tabular}{|c|c|c|c|c|c|c|c|c|c|c|c|c|c|}
\hline \multirow{2}{*}{$\begin{array}{l}\text { GoFlo } \\
\text { bottle }\end{array}$} & \multirow{2}{*}{$\begin{array}{l}\text { depth } \\
(\mathrm{m})\end{array}$} & \multirow[b]{2}{*}{$\theta\left({ }^{\circ} \mathrm{C}\right)$} & \multirow[b]{2}{*}{ salinity } & \multirow{2}{*}{$\begin{array}{c}{\left[\mathrm{O}_{2}\right]} \\
(\mu \mathrm{mol} / \mathrm{kg})\end{array}$} & \multirow{2}{*}{$\begin{array}{c}\theta_{\sigma} \\
\left(\mathrm{kg} / \mathrm{m}^{3}\right)\end{array}$} & \multirow{2}{*}{$\begin{array}{l}\text { water } \\
\text { mass }\end{array}$} & \multicolumn{4}{|c|}{ Dissolved fraction } & \multicolumn{3}{|c|}{ Particulate fraction } \\
\hline & & & & & & & $\begin{array}{c}\text { replicates } \\
\left({ }^{*}\right)\end{array}$ & $\begin{array}{c}{[\mathrm{DFe}]} \\
(\mathrm{nM})\end{array}$ & $\begin{array}{c}\delta^{56} \mathrm{DFe} \\
(\% 0) \\
\end{array}$ & 2SE (\%o) & $\begin{array}{c}{[\mathrm{PFe}]} \\
(\mathrm{nM})\end{array}$ & $\begin{array}{c}\delta^{56} \mathrm{PFe} \\
(\%)( \\
\end{array}$ & 2SE (\%) \\
\hline \multicolumn{14}{|c|}{ Station 28 , cast TM56, 09/28/2006, bottom $=2256 \mathrm{~m}$} \\
\hline 10 & 40 & 27,77 & 34,67 & 181,32 & 22,22 & & - & 0,89 & 0,53 & 0,06 & 32,19 & - & - \\
\hline \multirow[t]{3}{*}{8} & 94 & 26,51 & 34,87 & 170,82 & 22,77 & & a & 0,45 & 0,36 & 0,06 & 4,64 & - & - \\
\hline & & & & & & & a & 0,45 & 0,44 & 0,08 & & & \\
\hline & & & & & & & mean & 0,45 & 0,40 & & & & \\
\hline \multirow[t]{3}{*}{7} & 191 & 18,9 & 35,49 & 131,45 & 25,42 & SPEW & b & 0,67 & 0,45 & 0,08 & 6,97 & 0,29 & 0,06 \\
\hline & & & & & & & $b$ & 0,67 & 0,42 & 0,08 & & & \\
\hline & & & & & & & mean & 0,67 & 0,43 & & & & \\
\hline 5 & 321 & 12,88 & 35,02 & 147,61 & 26,43 & $13 \mathrm{CW}$ & - & 0,77 & 0,29 & 0,06 & 7,78 & 0,05 & 0,07 \\
\hline \multirow[t]{5}{*}{2} & 799 & 5,48 & 34,50 & 143,18 & 27,22 & AAIW & $b$ & 1,46 & 0,07 & 0,08 & 9,63 & $-0,02$ & 0,09 \\
\hline & & & & & & & $b$ & 1,46 & 0,08 & 0,08 & & & \\
\hline & & & & & & & $b$ & 1,46 & 0,02 & 0,07 & & & \\
\hline & & & & & & & $b$ & 1,46 & 0,06 & 0,07 & & & \\
\hline & & & & & & & mean & 1,46 & 0,06 & & & & \\
\hline \multicolumn{14}{|c|}{ Station 14, cast TM28, 09/10/2006, bottom $=5260 \mathrm{~m}$} \\
\hline 12 & 14 & 30,35 & 34,66 & 183,30 & 21,35 & & - & 0,06 & - & - & 0,41 & 0,26 & 0,07 \\
\hline 10 & 99 & 29,41 & 35,39 & 182,62 & 22,22 & & - & 0,06 & 0,58 & 0,07 & 0,47 & 0,46 & 0,07 \\
\hline 8 & 140 & 22,27 & 35,54 & 125,99 & 24,55 & SPEW & - & 0,20 & 0,31 & 0,08 & 0,58 & 0,14 & 0,08 \\
\hline \multirow[t]{3}{*}{6} & 198 & 14,75 & 34,83 & 129,79 & 25,90 & $13 \mathrm{CW}$ & a & 0,54 & 0,39 & 0,10 & 1,39 & 0,14 & 0,07 \\
\hline & & & & & & & a & 0,53 & 0,40 & 0,06 & & & \\
\hline & & & & & & & mean & 0,53 & 0,40 & & & & \\
\hline 4 & 400 & 9,24 & 34,68 & 57,64 & 26,83 & AAIW & - & 0,61 & 0,01 & 0,06 & 0,87 & 0,15 & 0,08 \\
\hline \multirow[t]{3}{*}{2} & 849 & 5,34 & 34,54 & 75,58 & 27,27 & AAIW & a & 0,57 & 0,22 & 0,04 & 0,51 & 0,27 & 0,09 \\
\hline & & & & & & & a & 0,61 & 0,22 & 0,05 & & & \\
\hline & & & & & & & mean & 0,59 & 0,22 & & & & \\
\hline
\end{tabular}

$\left(^{\star}\right) a$ indicates that the separation into several replicates has been performed before the chemical processing whereas $b$ indicates that the separation has been performed just before the analysis at the Neptune (MC-ICPMS). 


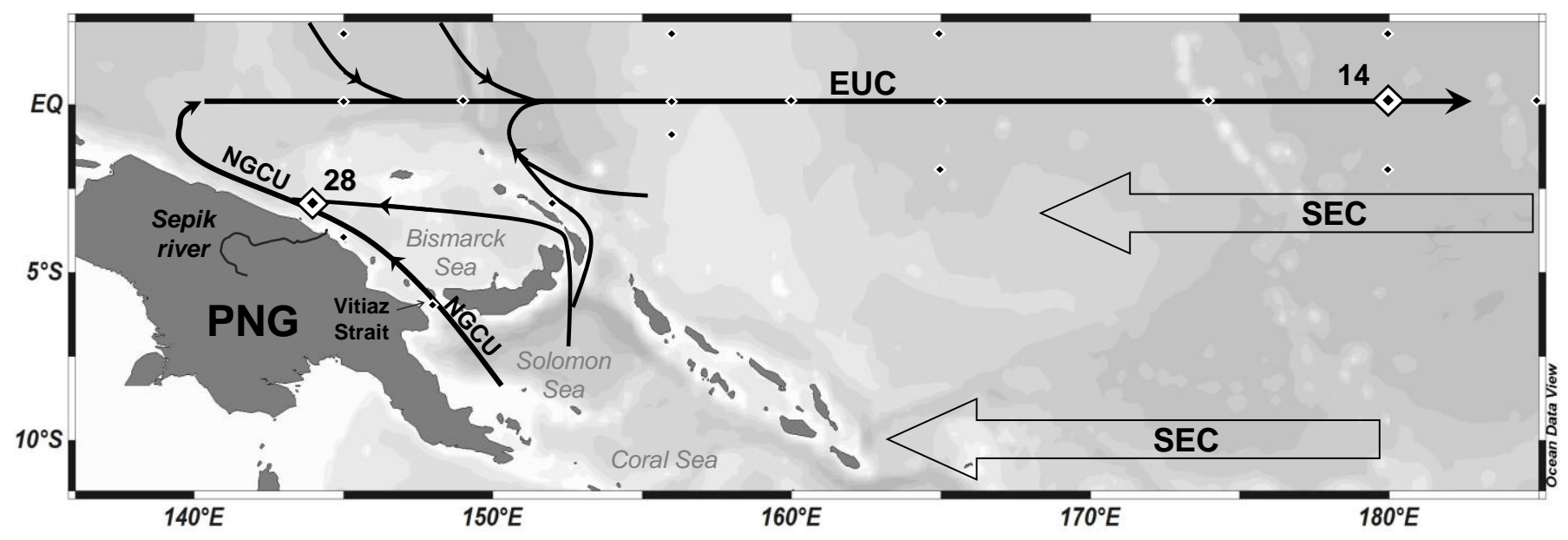

Figure 1 : Locations of stations 14 and 28 (EUCFe cruise, 2006) and main currents between 0 and $1000 \mathrm{~m}$ depth (adapted from Butt and Lindstrom, 1994) : the South Equatorial Current (SEC), the Equatorial Undercurrent (EUC), the New Guinea Coastal Undercurrent (NGCU). 

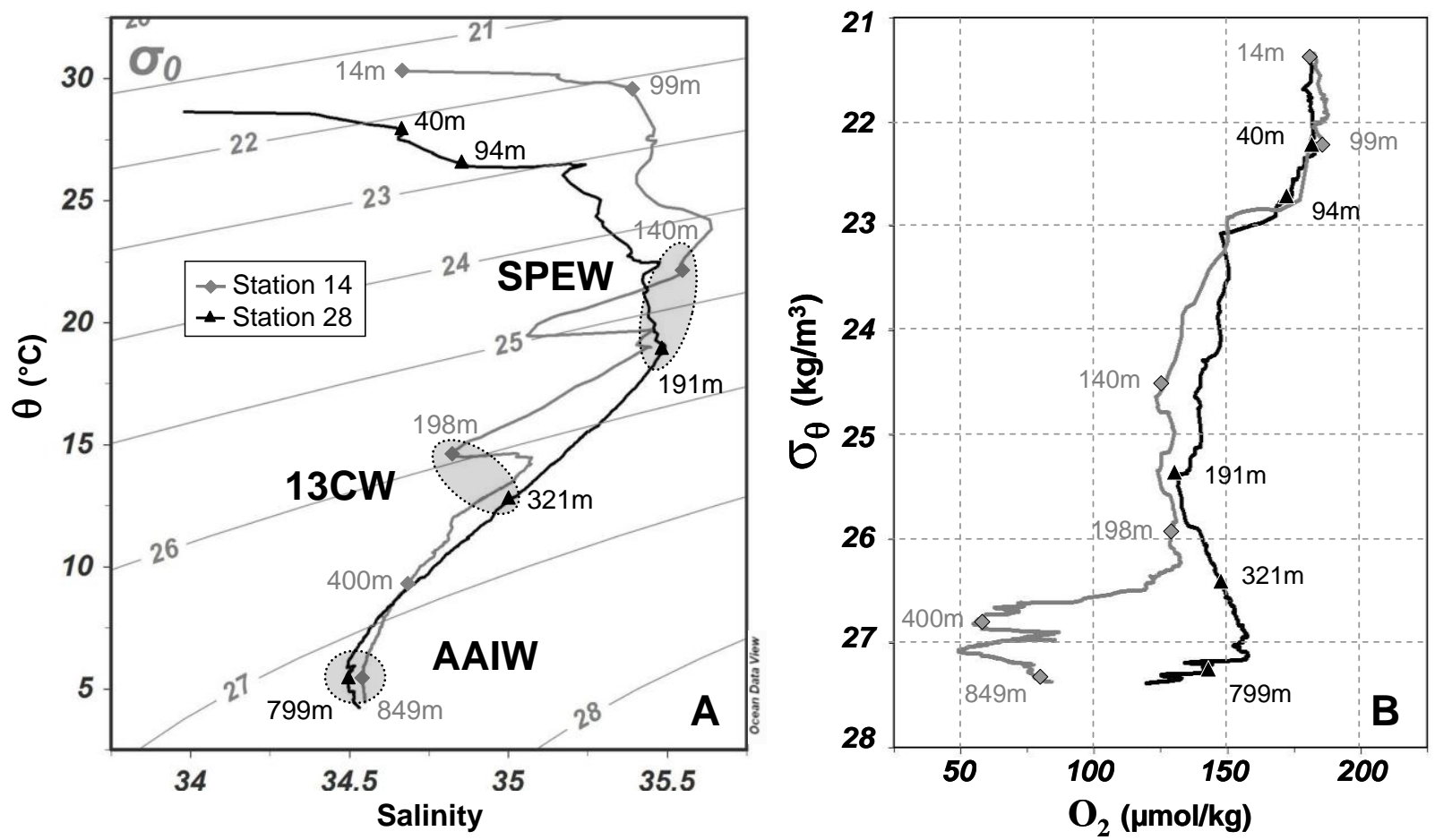

Figure 2: A) Potential temperature $(\theta)$ - salinity diagram. Potential density $\left(\sigma_{\theta}\right)$ are shown $\left(\right.$ in $\left.\mathrm{kg} \cdot \mathrm{m}^{-3}\right)$. B) dissolved oxygen concentration profiles for station 14 (in grey) and station 28 (in black). The samples presented in this study are indicated by symbols and their depths are reported (in meters). 


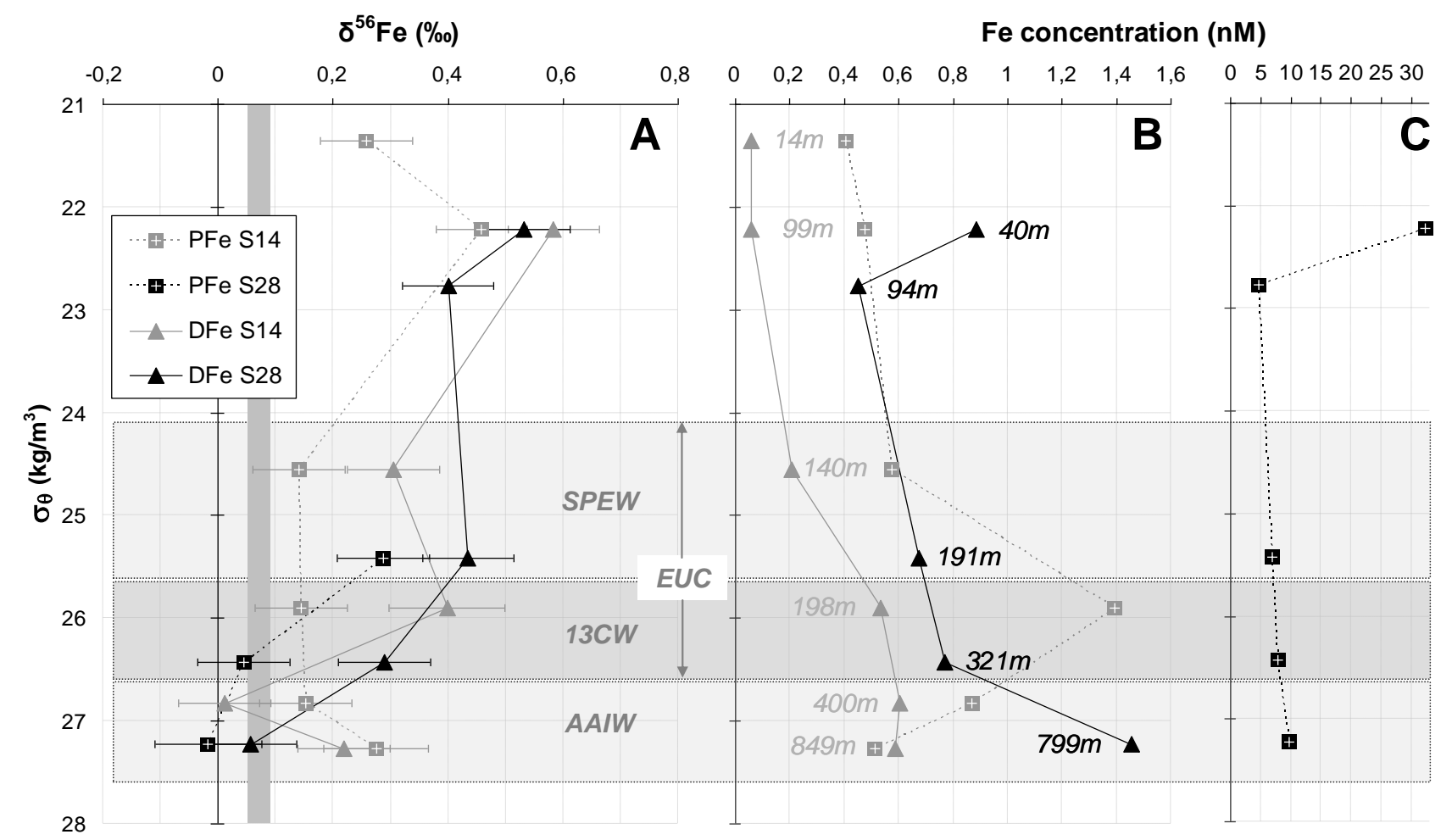

Figure 3: $\delta^{56} \mathrm{Fe}(\mathrm{A})$ and Fe concentration $(\mathrm{B}$ and $\mathrm{C})$ in dissolved and particulate fractions of seawater from station 14 and 28 , versus potential density. In $A$, the grey area indicates the crustal value (0.07 $\pm 0.02 \%$, $2 S D$; Poitrasson, 2006). In B and C, the error bar is smaller than the symbols. Depths are indicated in $B$ next to the data points. The large grey areas locate roughly the density of the water masses (SPEW, 13CW, AAIW; see text for details) and the equatorial undercurrent (EUC). 


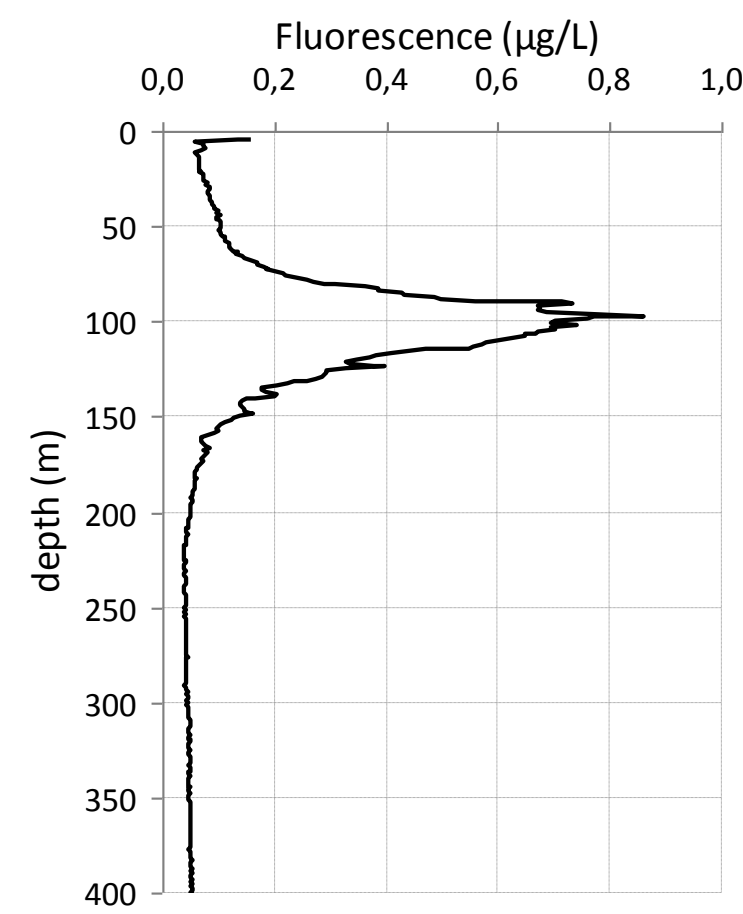

Figure 4 : Fluorescence profile measured at station 14 during EUCFe cruise (from the EUCFe website, ) 


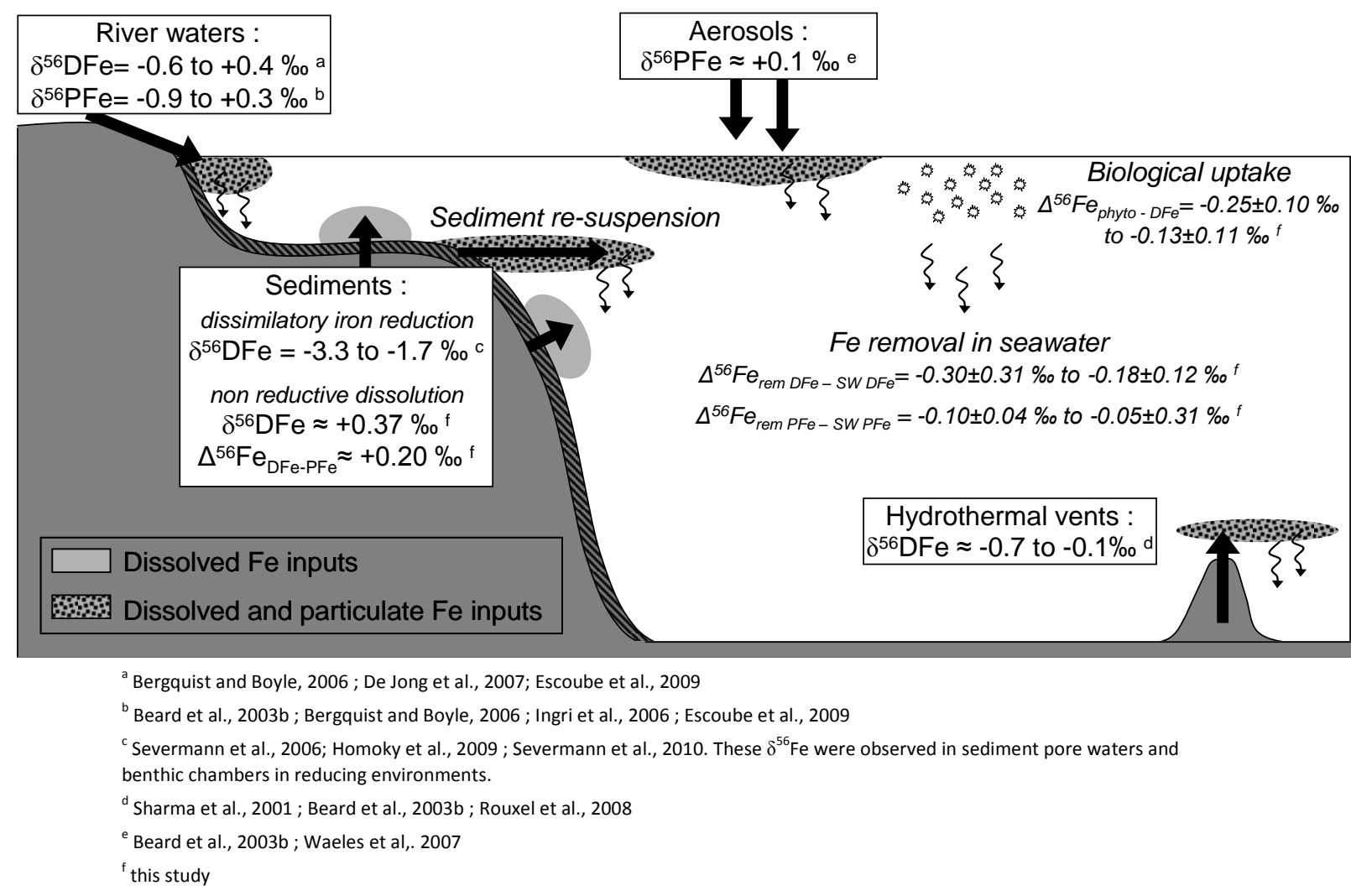

Figure 5 : Schematic representation of the iron isotope cycle in the ocean inferred from literature and from this study. The isotopic signatures of the main iron sources to seawater are represented. Estimates of the isotopic fractionations (in $\Delta^{56} \mathrm{Fe}$ notation) associated with biological uptake and $\mathrm{Fe}$ removal in the water column are also shown but they have to be considered cautiously. See the discussion for more details. 